\title{
JPSE
}

(Journal of Physical Science and Engineering)

\section{The Impact of Electric Vehicle on Road Transportation in Indonesia: Energy Demand and $\mathrm{CO}_{2}$ Emission}

\begin{tabular}{|c|c|}
\hline $\begin{array}{l}\text { Received } \\
08 \text { August }\end{array}$ & A Y W Kurniawan ${ }^{*}$, A A Setiawan', and A Budiman' \\
\hline $\begin{array}{l}\text { Revised } \\
05 \text { October } 2020 \\
\text { Accepted for Publication } \\
19 \text { October } 2020 \\
\text { Published } \\
23 \text { October } 2020\end{array}$ & $\begin{array}{l}\text { 1. Department of System Engineering, Faculty of Engineering, Universitas Gadjah Mada, Jl. } \\
\text { Grafika 2, Yogyakarta, 55281, Indonesia. } \\
\text { 2. Department of Nuclear Engineering and Physics Engineering, Faculty of Engineering, } \\
\text { Universitas Gadjah Mada, Jl. Grafika 2, Yogyakarta, 55281, Indonesia. } \\
\text { 3. Department of Chemical Engineering, Faculty of Engineering, Universitas Gadjah Mada, Jl. } \\
\text { Grafika 2, Yogyakarta, 55281, Indonesia. }\end{array}$ \\
\hline & *E-mail: arif.yulianto.w@mail.ugm.ac.id \\
\hline $\begin{array}{l}\text { (C) } \\
\text { (1) } \\
\text { This work is licensed } \\
\text { under a Creative } \\
\text { Commons Attribution- } \\
\text { ShareAlike } 4.0 \\
\text { International License }\end{array}$ & $\begin{array}{l}\text { Abstract } \\
\text { Light Duty Vehicle (LDV) for road transportation in Indonesia is the biggest energy } \\
\text { consumption with most of the energy carriers from refined fuel oil with high } \mathrm{CO}_{2} \\
\text { emission. Battery Electric Vehicle (BEV) is one of the alternatives to reduce oil } \\
\text { consumption and } \mathrm{CO}_{2} \text { emission on the road transportation sector. This research is carried } \\
\text { to analyse impact on BEV on energy demand and carbon emission. Modified Mobility } \\
\text { Model (MoMo) with PUCE methods was developed to projecting road transportation } \\
\text { demand in Indonesia. This research shows that road transportation will reach } 519 \text { MBoe } \\
\text { in } 2040 \text { with } 83.6 \% \text { from refined fuel oil. With moderate EV, energy will be reduced by } \\
31 \text { MBoe ( } 6 \% \text { ), and refined fuel oil reduced by } 8.5 \% \text {. With a high EV scenario, energy } \\
\text { will be reduced by } 57 \mathrm{MBoe}(14 \%) \text { and refined fuel oil reduced by } 16 \% \text {. } \mathrm{CO}_{2} \text { emission } \\
\text { will be reduced up to } 4.8 \text { to } 8.8 \% \text { in } 2040 \text {. } \\
\text { Keywords: Road transportation, modified mobility model, battery electric vehicle. }\end{array}$ \\
\hline
\end{tabular}

\section{Introduction}

Transportation is the biggest energy consumer in Indonesia, with $362 \mathrm{MBoe}$ or $46.6 \%$ of national energy consumption in 2017 [1]. It is in line with increasing refined fuel oil (gasoline and diesel oil) consumption since limited alternative energy carrier is available for transportation. Road transportation is the biggest consumer for fuel oil with $88 \%$ from total production [2]. Road transportation requires energy carriers that are easy to store and distributed to meet mobility purposes; therefore fossil fuel still becomes the biggest contribution by $99.3 \%$ or 277 MBoe in 2017 [3]. With Indonesian oil production getting lower, it will cause a massive energy gap to be filled. The increase in the utilization of fossil fuel for road transportation will increase $\mathrm{CO} 2$ emission. Road transportation is the 2nd biggest $\mathrm{CO} 2$ emission in Indonesia, with 117.9 million Mton $\mathrm{CO}_{2}$ or $25.9 \%$ of total $\mathrm{CO}_{2}$ emission [4].

Battery Electric Vehicle (BEV) is one of the alternatives to be used for road transportation. BEV are three to five more energy-efficient than conventional internal combustion engines [5] and will lead to lower energy consumption. Electrical power generation has various primary energy sources include a renewable energy source. Therefore it will reduce dependency on refined fuel oil in the future. Zero GHG emission from BEV will play a key role in the low-carbon footprint program. As developed countries, Indonesia is facing difficulties in maintaining load factor, therefore high utilization and smart grid of BEV with a controllable charging period, will improve the load factor [6], increase power system stability, and reduce power system operating cost [7].

Electrical energy in Indonesia is predominantly generated from fossil fuel-based electrical generation. Coal Fired Power Plant (CFPP) currently contributes the highest composition by $60 \%$ and follows by a gas power plant with 23\% [8]. With this composition, $\mathrm{CO}_{2}$ emission from power plant contributes approximately 267 million Mtons $\mathrm{CO}_{2}$ or $48 \%$ of total emission in Indonesia [2]. Decarbonizing emission program with $\mathrm{BEV}$ utilization depends on location, especially power generation composition. Average well to wheels $\mathrm{CO}_{2}$ emissions BEV cars are $102 \mathrm{gCO}_{2} / \mathrm{km}$ in US, 93 $\mathrm{gCO}_{2} / \mathrm{km}$ in UK, and $19 \mathrm{gCO}_{2} / \mathrm{km}$ in France [9]. Therefore, well-to-wheel analysis is needed to calculate the impact of BEV utilization in Indonesia. 


\section{Method}

\subsection{Calculation Methods}

Calculation methods in this study were modified Mobility Model (MoMo), which developed by International Energy Agency (IEA) for Energy Technology Perspectives (ETP) 2017 [10]. Fundamental models in MoMo is based on ASIF methodology (Activity-Structure-Intensity-Fuel) [11]. Anyhow in the case of LDV approach, these models shall be modified into PUCE methods (Parc-UseConsumption-Emission), with equation

$$
\mathrm{GHG}=\sum_{\text {Models Fuel }} \sum_{m . f} U_{m . f} C_{m . f} E_{m . f}
$$

where $G$ represents total energy or gaseous emission, $P$ represent the number of vehicles, $U$ represent the use of the vehicles, $C$ represents energy intensity or consumption, and $E$ represents emission characteristic [12]. Modified Mobility Models (MoMo) are shown on Figure 1.

\subsection{Vehicle Stocks Calculation}

Vehicle stocks calculation based on stock turn over methods. Sales and survival rate was the input on the stock vintage year with the following equation

$$
\begin{aligned}
\text { Stocks }_{t, y, v} & =\left(\text { Sales }_{t, y} \cdot \text { Survival }_{t, y-v}\right) \\
\text { Stock }_{t, y, v} & =\sum_{v=0 . \ldots T} \text { Stocks }_{t, y, v}
\end{aligned}
$$

where $t$ is the type of vehicle, $v$ is vintage or model year, $y$ is a calendar year, and $T$ is the number of types of vehicles.

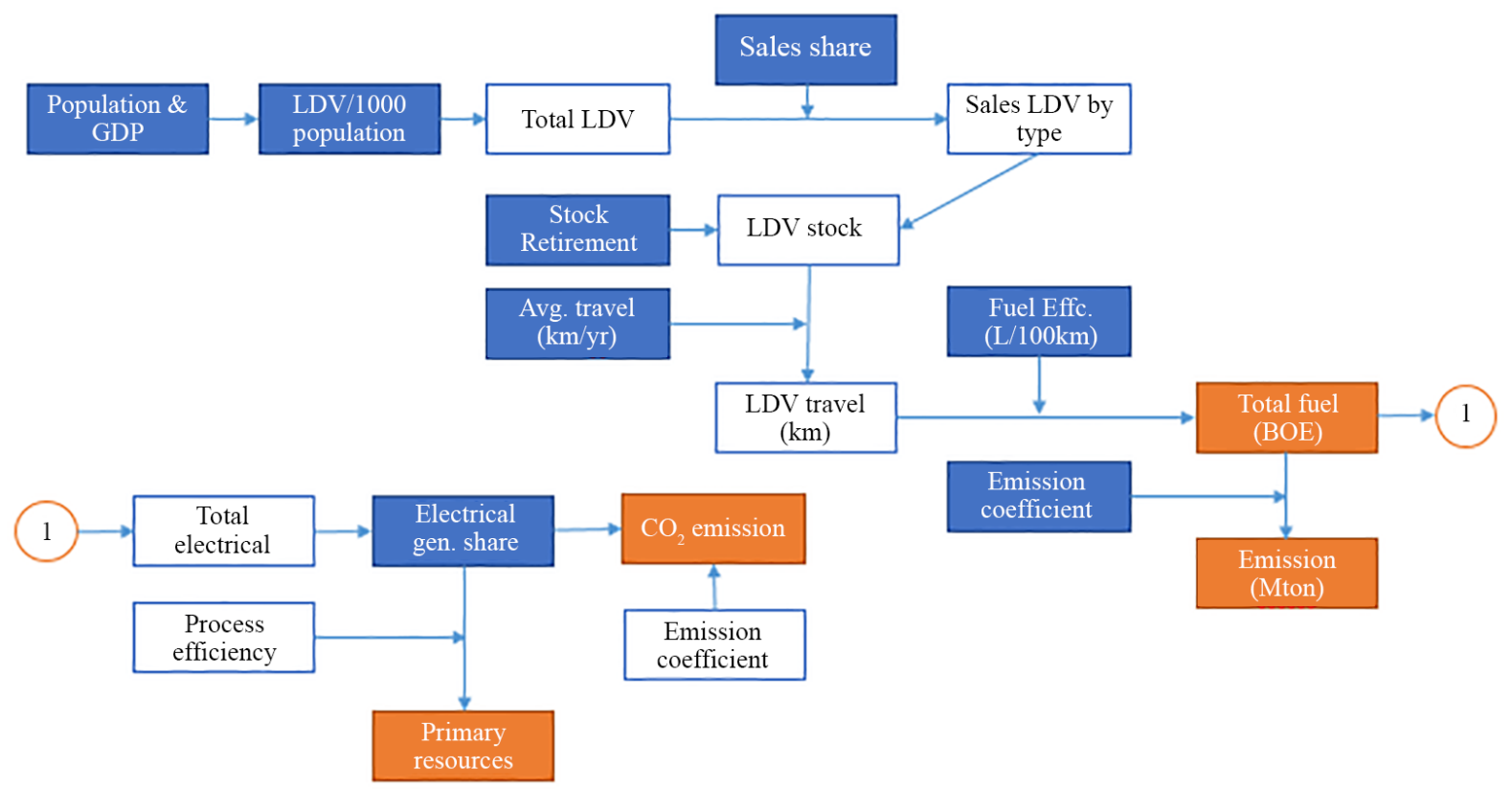

Figure 1. Flow diagram of modified PUCE methodology for LDV in the models. 


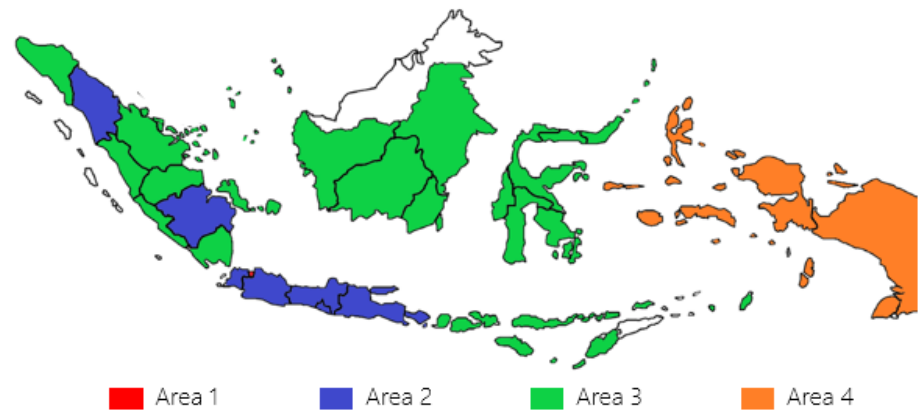

Figure 2. Indonesia territory was clustered into 4 areas.

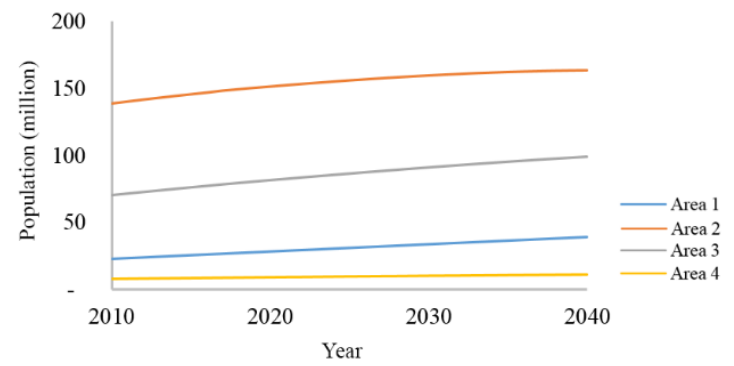

(a)

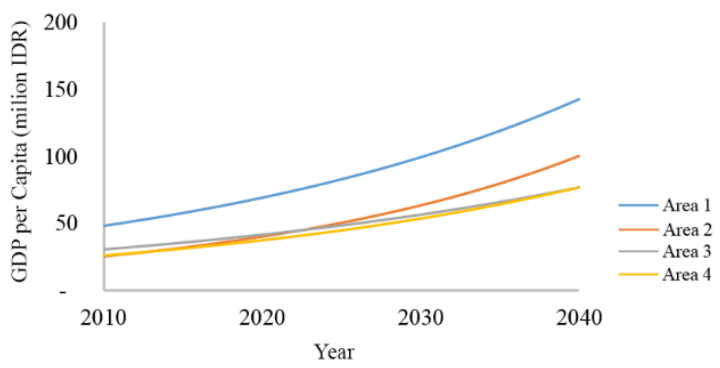

(b)

Figure 3. (a) Population projection, and (b) GDP per capita projection.

In this model, Indonesian territory was clustered into 4 areas (Figure 2) which have similarities in road infrastructure, public transport, access sources of energy for transportation, and population density, as seen in Figure 3 [13]. This clustered area will affect the scenario development where the BEV penetration will be focused on area 1 and area 2. Techno-economic modeling was used to develop LDV ownership shown in Figure 4 [14].

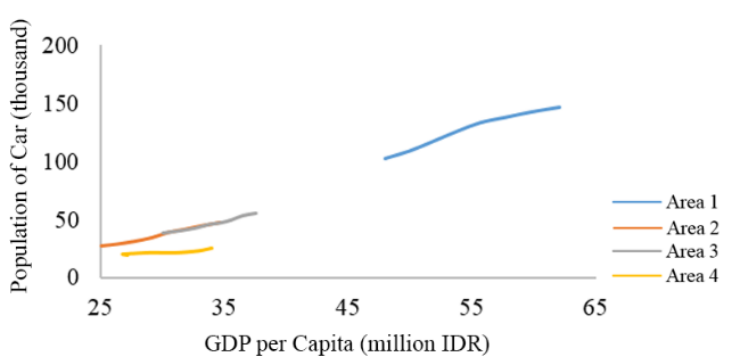

(a)

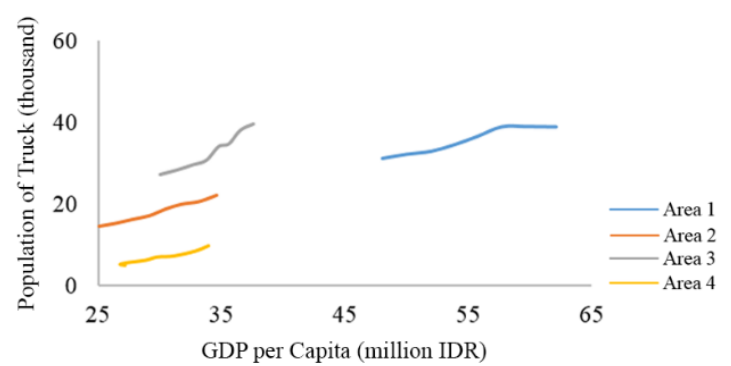

(c)

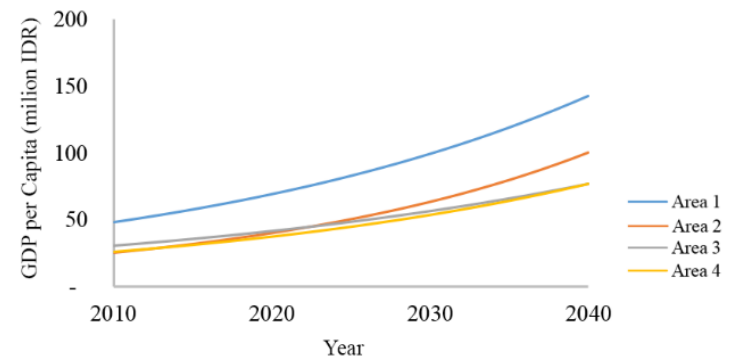

(b)

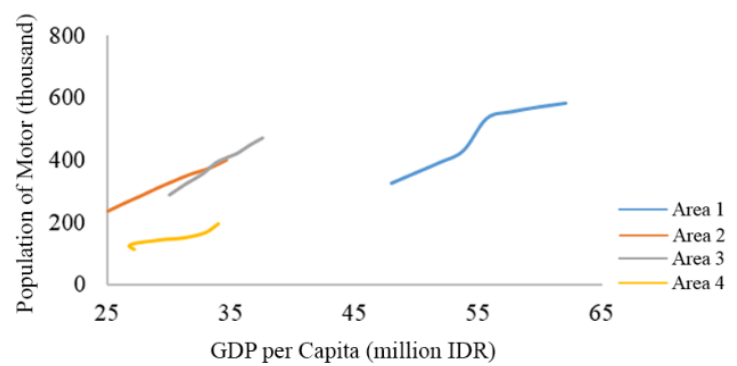

(d)

Figure 4. LDV/1000 population per GDP per capita for (a) car, (b) bus, (c) truck, and (d) motor. 


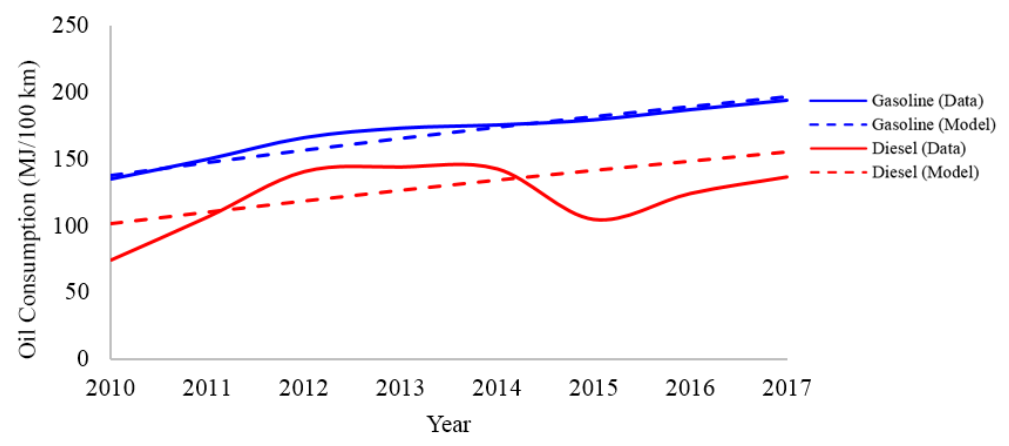

Figure 5. Model validation on oil consumption.

\subsection{Model Validation}

Methods to validate models compare the oil consumption for road transportation from 2010 to 2017, as seen in Figure 5. We compare gasoline and diesel consumption between data and output models. It shows that real consumption and models on both gasoline and diesel have a similar trend.

\subsection{Scenario and Assumption}

Three scenarios were developed in this research as seen in Table 1. Developed scenario based on electrical power generation data (as shown on Table 2) [16] and vehicle energy intensity, economics, and emission for each vehicle (as shown on Table 3) [9], [17]-[20]. In scenario 1 or Business as Usual $(\mathrm{BaU})$, no electric vehicles on this scenario. In scenario 2 or medium BEV penetration, sales on BEV will be $25-35 \%$ in 2040 on private cars, buses, and motorcycles in area 1 and area 2 . Meanwhile, for scenario 3 or optimist BEV penetration, sales on BEV will be $50-70 \%$ in 2040 on private cars, buses, and motorcycles in area 1 and area 2.

Table 1. Developed scenario.

\begin{tabular}{|c|c|c|}
\hline Scenario & Technology Option & Remarks \\
\hline 1 & Business as usual & $\begin{array}{ll}\circ & \text { Current situation and government regulation } \\
\circ & \text { No introduce on FCEV \& BEV } \\
\circ & \text { Biodiesel } 40 \% \text { in } 2040[15]\end{array}$ \\
\hline 2 & $\begin{array}{l}\text { Medium BEV } \\
\text { penetration }\end{array}$ & $\begin{array}{l}\text { BEV technology penetration } \\
\text { - Private car: } 25-35 \% \text { in } 2040 \\
\text { - Bus: } 30-35 \% \text { in } 2040 \\
\text { - Motorcycle: } 30-35 \% \text { in } 2040 \\
\circ \text { Electrical power generated from mixed energy sources } \\
\circ \text { Biodiesel 40\% in } 2040 \text { [15] }\end{array}$ \\
\hline 3 & $\begin{array}{l}\text { Optimist BEV } \\
\text { penetration }\end{array}$ & $\begin{array}{l}\text { BEV technology penetration } \\
\text { - Private car: } 50-60 \% \text { in } 2040 \\
\text { - Bus: } 50-70 \% \text { in } 2040 \\
\text { - Motorcycle: } 50-65 \% \text { in } 2040 \\
\circ \text { Electrical power generated from mixed energy sources } \\
\circ \text { Biodiesel } 40 \% \text { in } 2040[15]\end{array}$ \\
\hline
\end{tabular}

Table 2. Electrical power generation data.

\begin{tabular}{lllcc}
\hline Process & Input & Output & $\begin{array}{c}\text { Efficiency } \\
(\%)\end{array}$ & $\begin{array}{c}\text { Environment } \\
\left(\mathrm{MT} \mathrm{CO}_{2} / \mathrm{TJ}\right)\end{array}$ \\
\hline Coal & Coal & Electricity & 48 & 25.8 \\
\hline Gas & Natural Gas & Electricity & 55 & 65.3 \\
\hline Renewable & RE Source & Electricity & - & - \\
\hline
\end{tabular}


JPSE (Journal of Physical Science and Engineering), Vol. 5, No. 2, 2020, Page 36-45.

Table 3. Vehicle energy intensity, economic, and emission.

\begin{tabular}{llccc}
\hline Vehicle & Type & $\begin{array}{c}\text { Intensity }(U) \\
(\mathrm{k} . \mathrm{km} / \mathrm{year})\end{array}$ & $\begin{array}{c}\text { Consumption }(C) \\
(\mathrm{MJ} / 100 \mathrm{~km})\end{array}$ & $\begin{array}{c}\text { Emission }(E) \\
(\mathrm{MT} / \mathrm{TJ})\end{array}$ \\
\hline \multirow{3}{*}{ Car } & Gasoline & $10.0-14.0$ & $23-368$ & 68.6 \\
\cline { 2 - 5 } & Diesel & $10.0-14.0$ & $188-289$ & 73.3 \\
\cline { 2 - 5 } & Electric & $10.0-14.0$ & 73 & - \\
\hline \multirow{2}{*}{ Bus } & Diesel & $40.0-50.0$ & $1,505-2,310$ & 73.3 \\
\cline { 2 - 5 } & Electric & $40.0-50.0$ & 590 & - \\
\hline \multirow{2}{*}{ Truck } & Diesel & $40.0-60.0$ & $942-1257$ & 68.3 \\
\hline \multirow{2}{*}{ Motorcycle } & Gasoline & $8.5-10.0$ & $110-150$ & - \\
\cline { 2 - 5 } & Electric & $8.5-10.0$ & 26 & \\
\hline
\end{tabular}

\section{Results and Discussion}

\subsection{Vehicle Sales, Stocks, and Mileage}

Battery electric cars, city buses, and motorcycles are currently available on the market. Meanwhile, for trucks and intercity buses, battery electric-based vehicles still being developed in the future. In this research, only three types of vehicles replaced by BEV are car, bus, and motorcycle. Figure 6-8 shows each scenario developed on BEV penetration. In scenario 1 or BaU, no BEV technology on LDV sales (Figure 6.a, 7.a, and 8.a). In scenario 2 with medium BEV penetration, the electric car will reach $21 \%$ from all car sales or 283,000 units (Figure 6.b), an electric bus with 13\% or 6,000 units (Figure 7.b), and motorcycle with $21 \%$ or 2 million units 2040 (Figure 8.b). In scenario 3 with optimistic BEV penetration, electric cars will reach $39 \%$ from all car sales or 525,000 units (Figure 6.c), electric bus with $22 \%$ or 9,000 units (Figure 7.c), and motorcycle $36 \%$ or 3.5 million units in 2040 (Figure 8.c).

Figure 9-11 show total stocks or active vehicles on each LDV type. In scenario 2 , the total active electric car will be 2.5 million units or $11 \%$ (Figure 9.b), electric bus will be 63,000 units or $6 \%$ (Figure 10.b), and electric motor will be 15.6 million units or $11 \%$ in 2040 (Figure 11.b). In scenario 3, total active electric car will be 4.6 million units or $21 \%$ (Figure 9.c), electric bus will be 107,000 units or $10 \%$ (Figure 10.c), and electric motor will be 28.8 million units or $21 \%$ in 2040 (Figure 11.c).

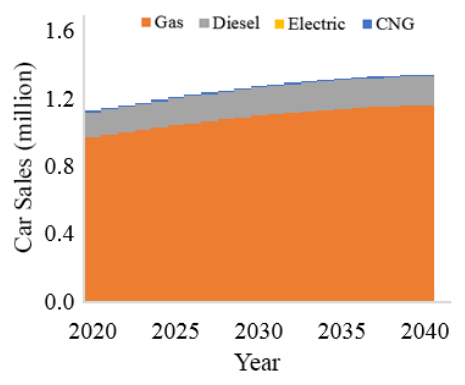

(a)

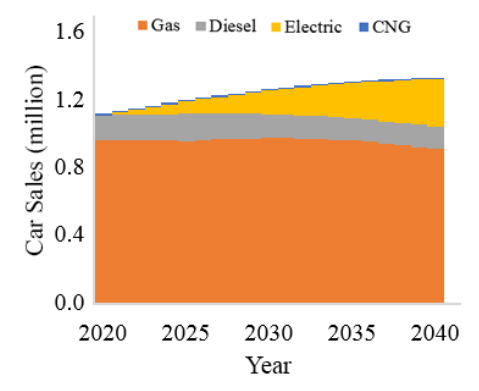

(b)

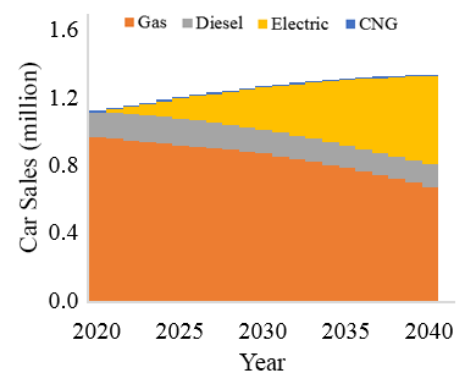

(c)

Figure 6. Car sales in (a) scenario 1, (b) scenario 2, and (c) scenario 3.

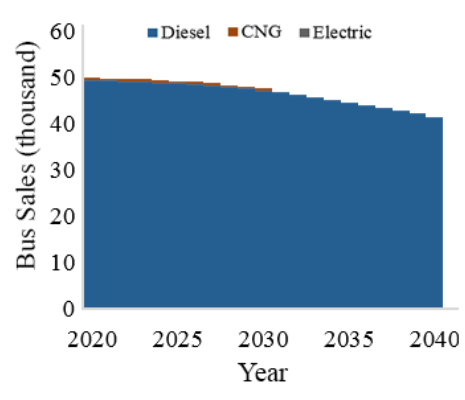

(a)

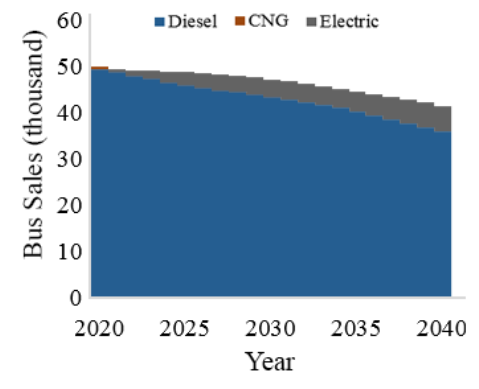

(b)

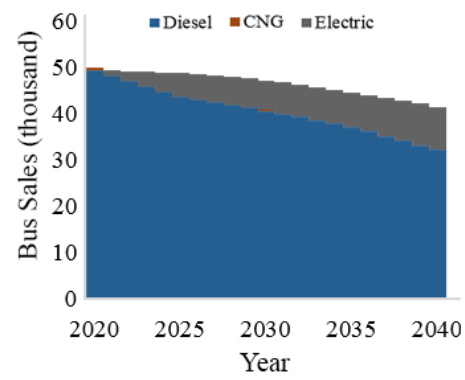

(c)

Figure 7. Bus sales in (a) scenario 1, (b) scenario 2, and (c) scenario 3. 


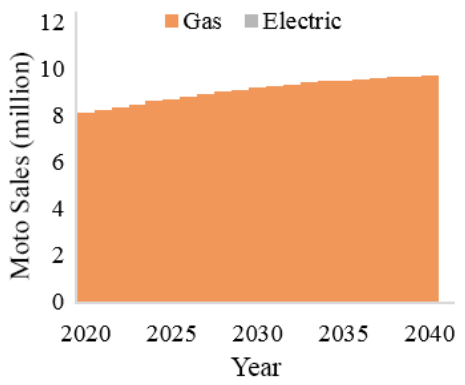

(a)

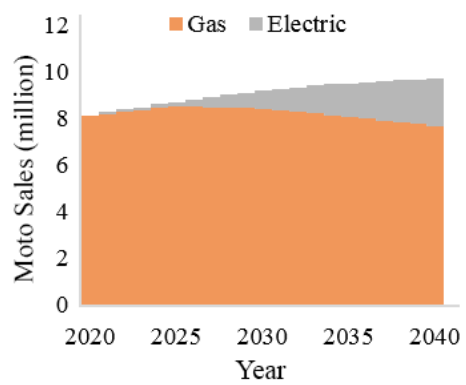

(b)

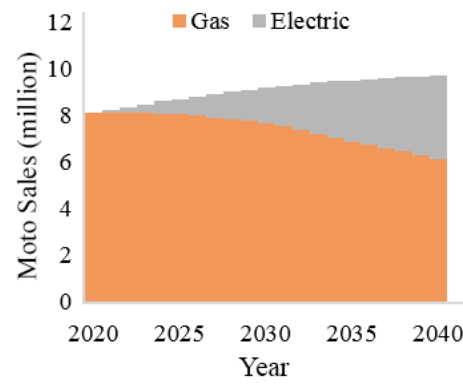

(c)

Figure 8. Motor sales in (a) scenario 1, (b) scenario 2, and (c) scenario 3.

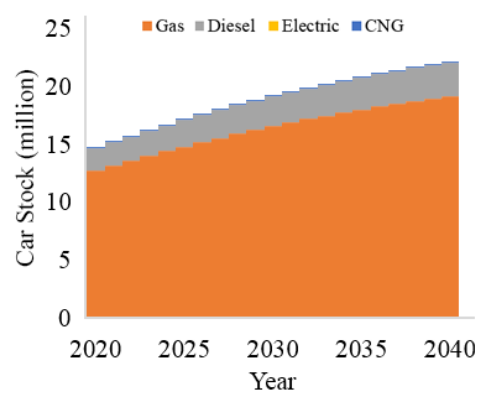

(a)

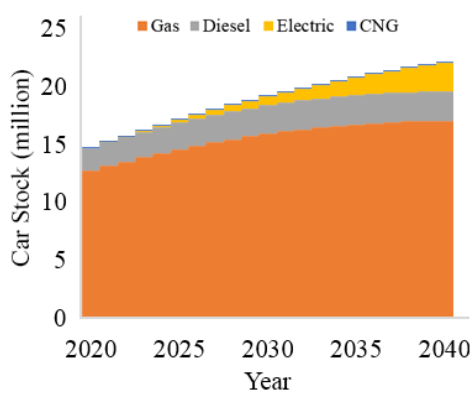

(b)

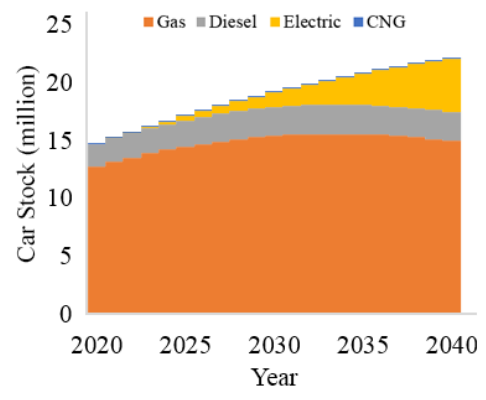

(c)

Figure 9. Car stocks in (a) scenario 1, (b) scenario 2, and (c) scenario 3.

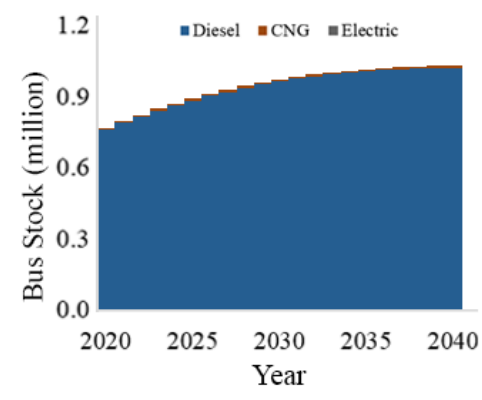

(a)

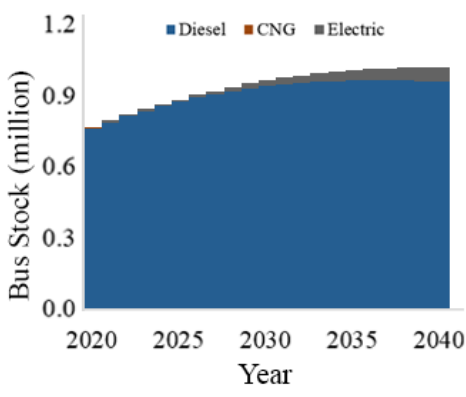

(b)

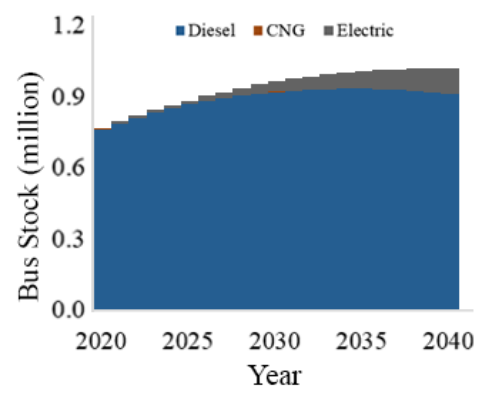

(c)

Figure 10. Bus stocks in (a) scenario 1, (b) scenario 2, and (c) scenario 3.

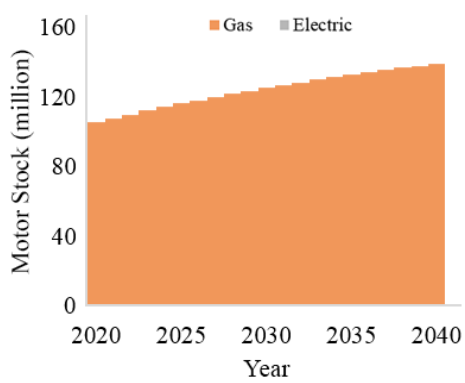

(a)

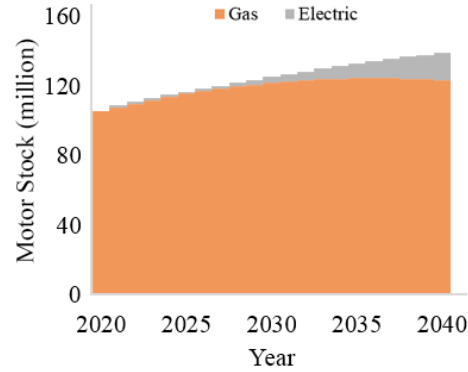

(b)

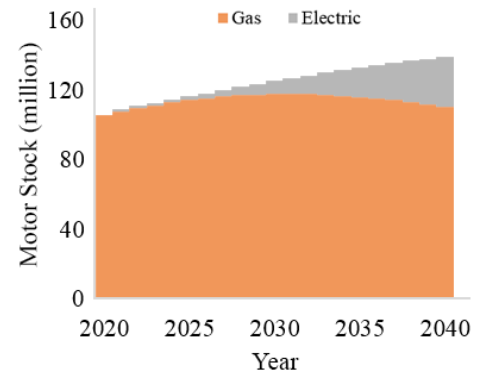

(c)

Figure 11. Motor stocks in (a) scenario 1, (b) scenario 2, and (c) scenario 3. 


\subsection{Energy Demand}

Figure 12 and 13 shows the energy demand on-road transportation in Indonesia. In scenario 1, total energy demand will reach 519 MBoe in 2040 (Figure 12.a), 38\% from the motorcycle and 33\% from trucks (Figure 13.a). In scenario 2, with medium BEV penetration on car, bus, and motor, total energy demand on road transportation will be reduced by 30.9 MBoe (Figure 12.b) or 6.3\% compared to scenario 1 (Figure 13.b). BEV on the motorcycle is expected to be the main contributor for energy reduction by $19.8 \mathrm{MBoe}$ or $11.2 \%$. Furthermore, in scenario 3 with optimist BEV penetration, total energy demand will be reduced by 56.9 MBoe (Figure 12.c) or $12.3 \%$ (Figure 13.c). Both motorcycle and cars are expected to be the main contributor to energy demand reduction by 36.5 MBoe and 15.2 MBoe. Therefore, in 2040, trucks will be the biggest consumer in road transportation with $37.2 \%$ since BEV technology can replace ICE on trucks.

Figure 14 and 15 shows energy demand by fuel for road transportation in Indonesia. In scenario 1, refined fuel oil (gasoline and diesel oil) will reach 434.4 MBoe in 2040 (Figure 14.a) or 84\% from total energy demand (Figure 15.a) and biodiesel consumption is 84.3 MBOE with B40 program for diesel oil (Figure 14.a). In scenario 2, refined fuel oil will be reduced by 36.8 MBoe (Figure 14.b) or $8.5 \%$ compared to scenario 1 (Figure 15.b). Meanwhile, electricity demand to feed BEV will reach 9.1 MBoe or 13.3 TWh in 2040. Higher BEV efficiency is the main role for energy demand reduction, as seen in Figure. In scenario 3, refined fuel oil will be reduced by 68.2 MBoe (Figure 14.c) or 15.7\% compared to scenario 1 (Figure 15.c). Meanwhile, electricity demand to feed BEV will reach $16.6 \mathrm{MBoe}$ or 24.1 TWh in 2040. Figure 16 shows average efficiency of car, bus, and motor. In scenario 2, average car efficiency will reach $11.3 \mathrm{~km} /$ liter or $12 \%$ higher than scenario 1 , average bus efficiency increased $2.23 \mathrm{~km} / 1 \mathrm{tr}$ or $5.2 \%$, and average motor efficiency will increase to $26.5 \mathrm{~km} / \mathrm{ltr}$ or $10.9 \%$ compared to scenario 1 . With a charging efficiency $90 \%$, energy demand for electric vehicles will be $14.7 \mathrm{TWh}$. In scenario 3, average car efficiency will reach $12.4 \mathrm{~km} /$ liter or $20.4 \%$ higher than scenario 1 , average bus efficiency also increased $2.32 \mathrm{~km} / 1 \mathrm{tr}$ or $9.4 \%$, and average motor efficiency increased $29.3 \mathrm{~km} / 1 \mathrm{tr}$ or $22.6 \%$ compared to scenario 1 . With a charging efficiency $85 \%$, the energy demand for electric vehicles will be $14.7 \mathrm{TWh}$. With a charging efficiency of $90 \%$, the energy demand for electric vehicles will be $26.8 \mathrm{TWh}$. It shows a good impact on the utilization of battery electric vehicles and reduces Indonesia with significant refined oil reduction, reduced energy demands, and higher average vehicle efficiency.

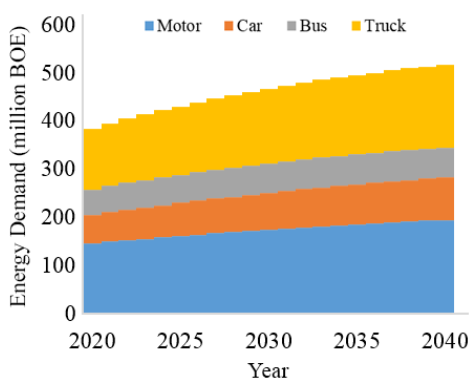

(a)

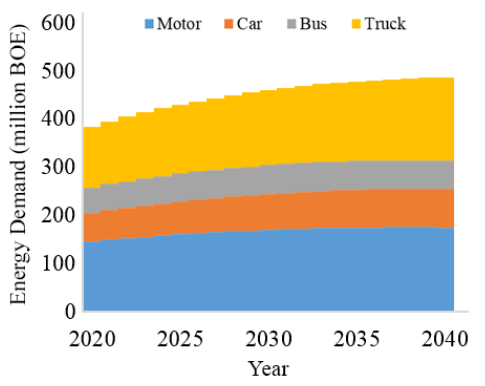

(b)

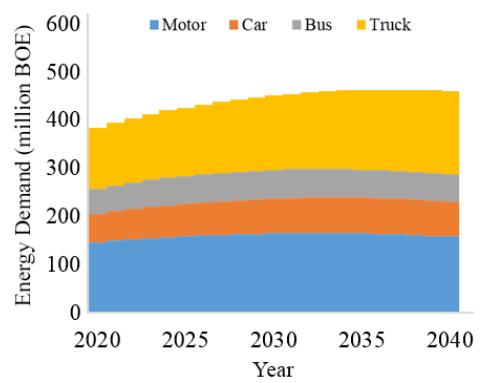

(c)

Figure 12. Energy demand (million BOE) by type of vehicle in (a) scenario 1, (b) scenario 2, and (c) scenario 3.

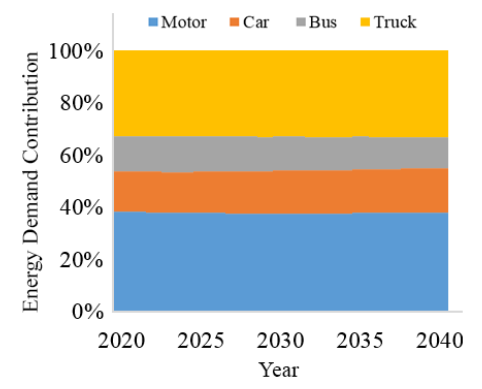

(a)

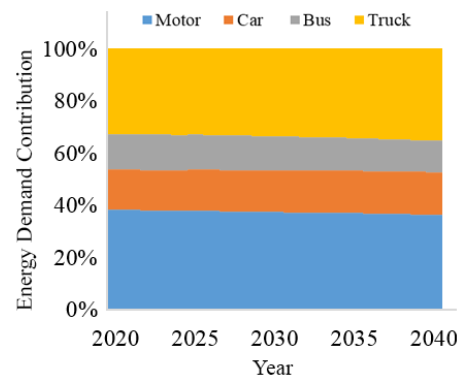

(b)

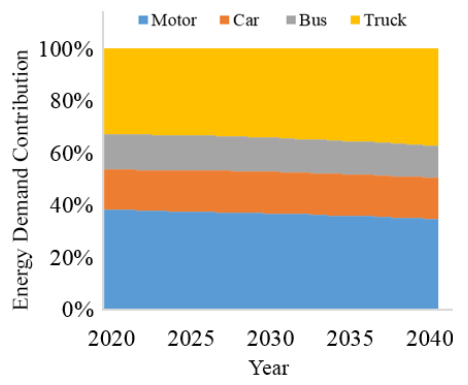

(c)

Figure 13. Energy demand contribution by type of vehicle in (a) scenario 1, (b) scenario 2, and (c) scenario 3. 


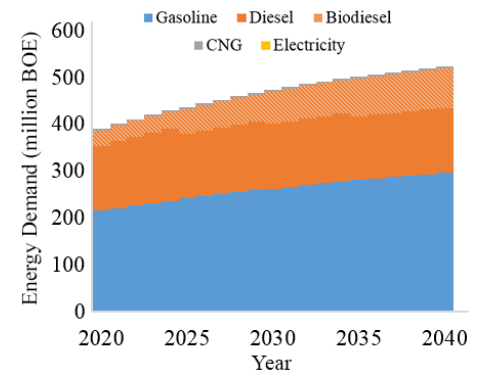

(a)

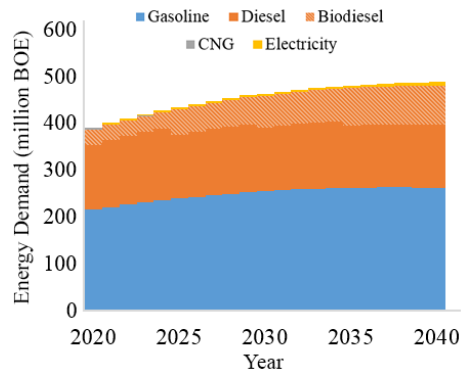

(b)

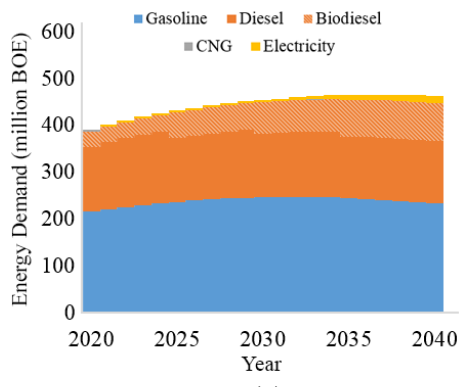

(c)

Figure 14. Energy demand (million BOE) by fuel in (a) scenario 1, (b) scenario 2, and (c) scenario 3.

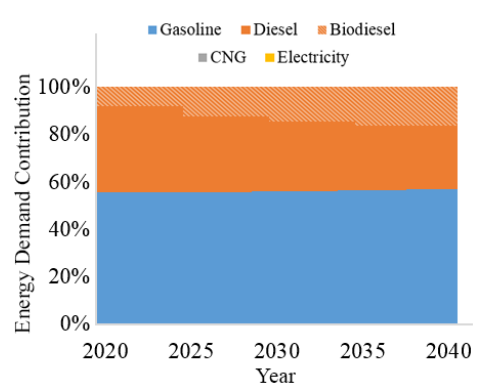

(a)

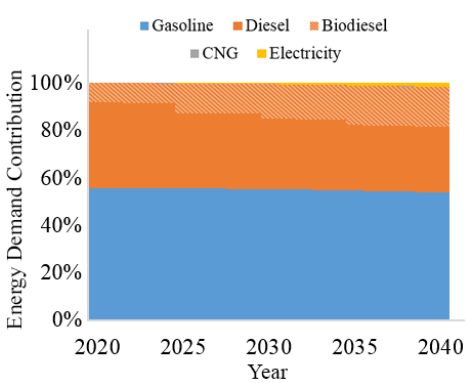

(b)

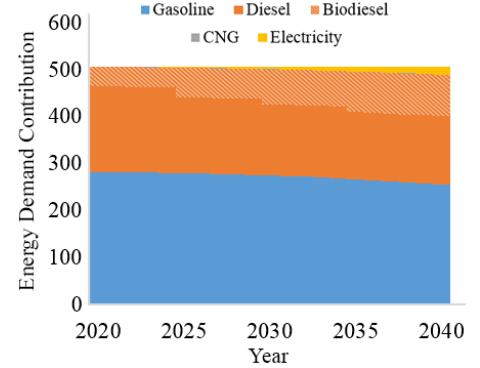

(c)

Figure 15. Energy demand contribution by fuel in (a) scenario 1, (b) scenario 2, and (c) scenario 3.

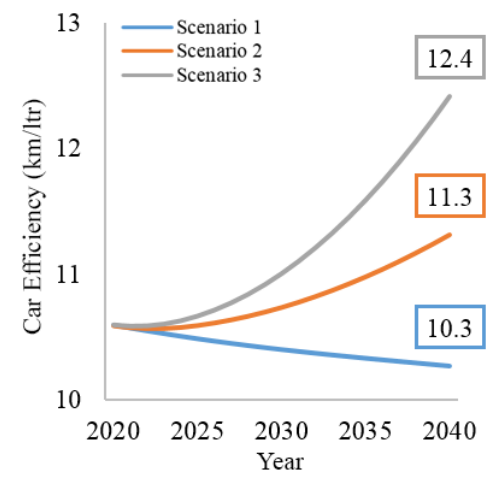

(a)

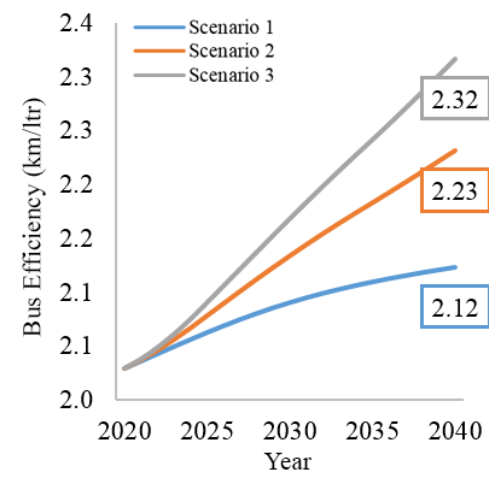

(b)

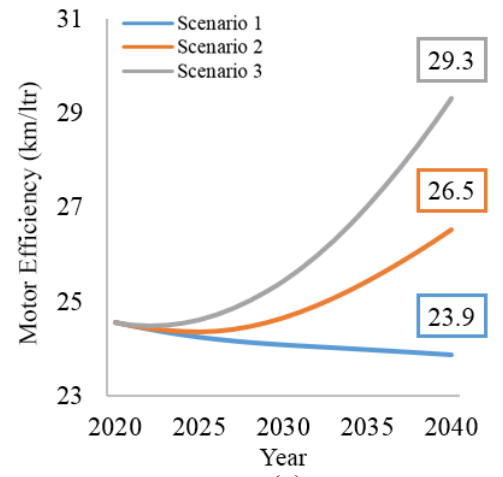

(c)

Figure 16. Average efficiency of (a) car, (b) bus, and (c) motor.

\subsection{Carbon Emission}

Figure 17 shows power generation contribution to feed energy for the electric vehicles. The power generation composition will affect $\mathrm{CO}_{2}$ emission as seen on Figure 18 and 19. In scenario 1, total emission on road transportation will reach 218 million $\mathrm{Mton}^{\mathrm{CO}_{2}}$ in 2040 (Figure 18.a). Emission from motor cycle is the main contributor with 82 million Mtons or 38\%. Followed by truck with 73 million Mtons or 34\% and car with 36 million Mtons or 36\% (Figure 19.a). In scenario 2, total emission from road transportation will be reduced to 202 million Mton (Figure 18.b) or 7.5\% lower than scenario 1 (Figure 19.b). Meanwhile emission from electric generation will be 6 million Mtons. Therefore, in total, emission will be reduced by 10 million Mtons or $4.8 \%$. In scenario 3, total emission from road transportation will be reduced to 188 million Mton (Figure 28.c) or 13.7\% lower than scenario 1 (Figure 19.c). Meanwhile, emission from electric generation will be 11 million Mtons. Therefore, in total, emission will be reduced by 19 million Mtons or $8.8 \%$. 


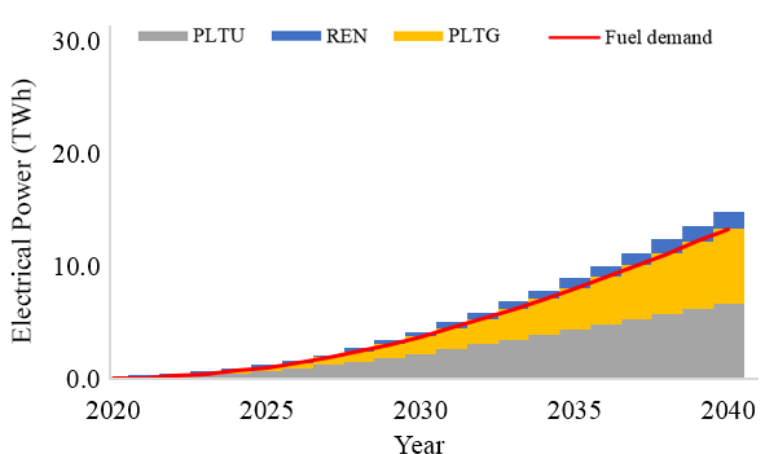

(a)

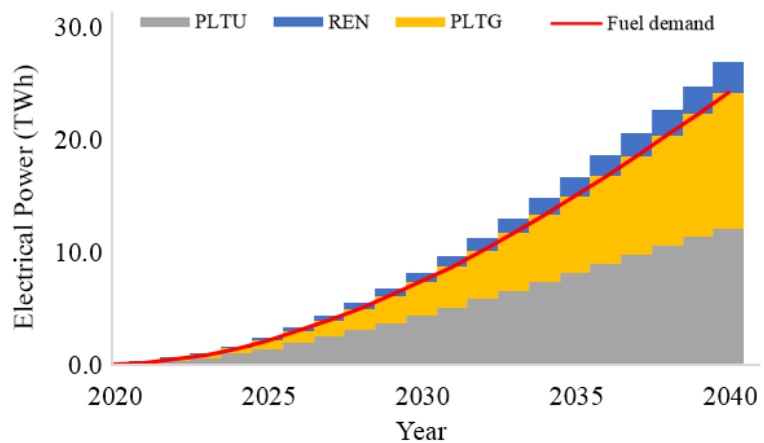

(b)

Figure 17. Electrical power generation source (TWh) in (a) scenario 2 and (b) scenarion 3.

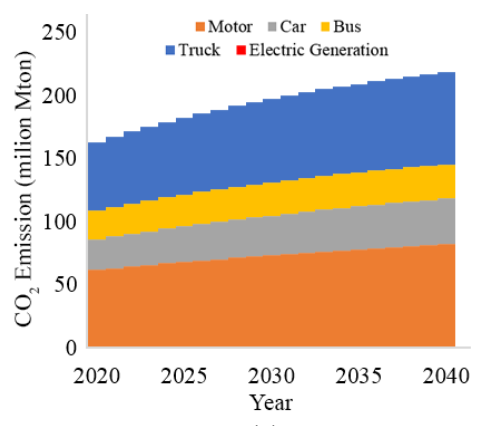

(a)

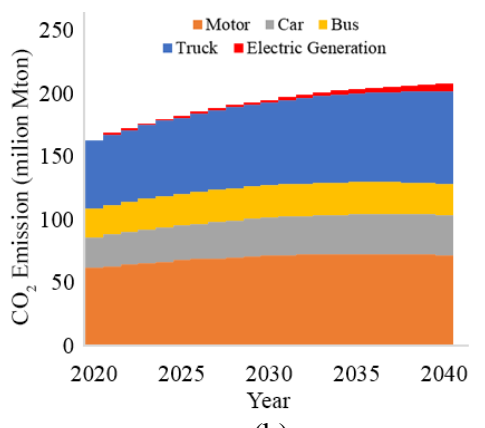

(b)

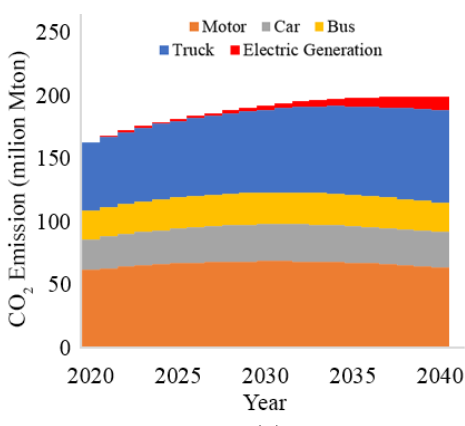

(c)

Figure 18. Carbon dioxide emission (million metric tons) in (a) scenario 1, (b) scenario 2, and (c) scenario 3.

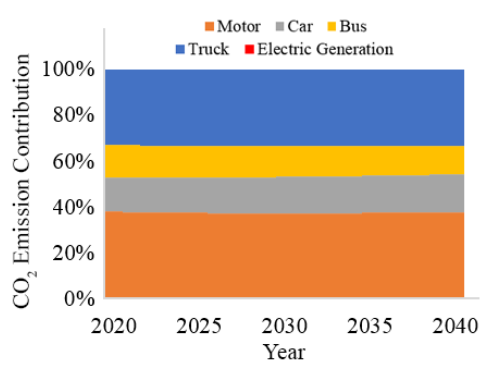

(a)

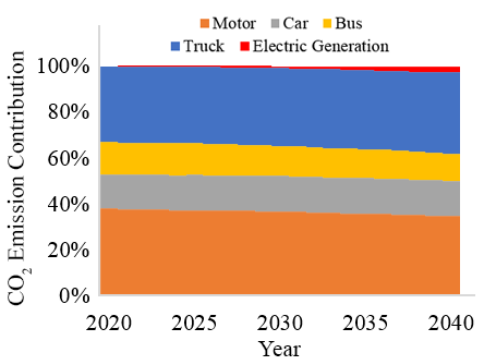

(b)

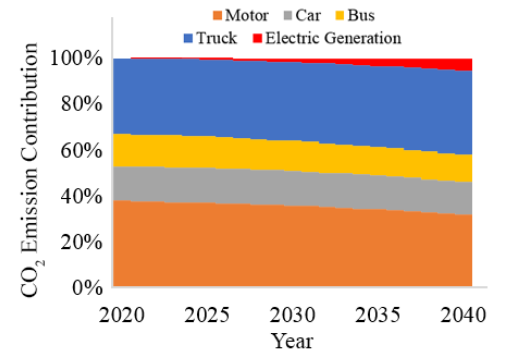

(c)

Figure 193. Carbon dioxide emission contribution in (a) scenario 1, (b) scenario 2, and (c) scenario 3.

Table 4. Comparison on utilization on battery electric vehicle in Indonesia.

\begin{tabular}{lccc}
\hline Description & BaU & Medium & Optimist \\
\hline Energy demand (MBOE) & 518.9 & 488.1 & 462.1 \\
\hline Energy reduction (\%) & 0.0 & 6.0 & 11.0 \\
\hline Electrical demand (TWh) & 0.0 & 14.7 & 26.8 \\
\hline Refined oil demand (MBOE) & 434.4 & 397.6 & 366.2 \\
\hline Refined oil reduction (\%) & 0.0 & 8.5 & 15.7 \\
\hline $\mathrm{CO}_{2}$ emission (million MT) & 218.3 & 207.9 & 199.0 \\
\hline $\mathrm{CO}_{2}$ reduction $(\%)$ & 0.0 & 4.8 & 8.8 \\
\hline
\end{tabular}




\section{Conclusion}

Utilization of battery electric vehicle in Indonesia especially on private sector on cars and motors have multiple benefits including a reduction on energy demands on-road transportation, reduction on importing refined fuel oil, and also total $\mathrm{CO}_{2}$ reduction even though composition on electrical power generation in Indonesia still dominated by coal and natural gas-based power plants.

\section{References}

[1] A. C. Adi et al., Eds. Handbook of Energy \& Economic Statistics of Indonesia. Jakarta: Ministry of Energy and Mineral Resources Republic of Indonesia, 2018.

[2] S. Abdurrahman et al., Eds. Indonesia Energy Outlook 2018. Jakarta: Ministry of Energy and Mineral Resources Republic of Indonesia, 2018.

[3] Subdirectorate of Statistical Mining and Energy, Energy Balances of Indonesia 2014-2018. Jakarta: BPS-Statistic Indonesia, 2019.

[4] International Energy Agency, $\mathrm{CO}_{2}$ Emissions from Fuel Combustion 2018 Highlights. Paris: International Energy Agency, 2018.

[5] International Energy Agency, Global EV Outlook 2019: Scaling-Up The Transition to Electric Mobility. Paris: International Energy Agency, 2019.

[6] M. Huda, M. Aziz, and K. Tokimatsu, "The future of electric vehicles to grid integration in Indonesia," Energy Proc., vol. 158, pp. 4592-4597, 2019.

[7] F. Mwasilu, J. J. Justo, E. K. Kim, T. D. Do, and J. W. Jung, "Electric vehicles and smart grid interaction: a review on vehicle to grid and renewable energy sources integration," Renew. Sust. Energ. Rev., vol. 34, pp. 501-516, 2014.

[8] I. Jonan, Rencana Umum Ketenagalistrikan Nasional 2019-2038. Jakarta: Kementerian Energi dan Sumber Daya Mineral, 2019.

[9] A. R. Holdway, A. R. Williams, O. R. Inderwildi, and D. A. King, "Indirect emissions from electric vehicles: emissions from electricity generation," Energy Environ. Sci., vol. 3, no. 12, p. $1825,2010$.

[10] International Energy Agency, Energy Technology Perspectives 2017. Paris: International Energy Agency, 2017.

[11] A. Widyaparaga et al., "Scenarios analysis of energy mix for road transportation sector in Indonesia," Renew. Sust. Energ. Rev., vol. 70, pp. 13-23, 2017.

[12] L. Fulton, P. Cazzola, and F. Cuenot, "IEA Mobility Model (MoMo) and its use in the ETP 2008," Energy Policy, vol. 37, no. 10, pp. 3758-3768, 2009.

[13] Subdirectorate of Demographic Statistics, Technical Note Indonesia Population Projection 20152045: Result of SUPAS 2015. Jakarta: BPS-Statistic Indonesia, 2018.

[14] Subdirectorate of Transportation Statistics, Land Transportation Statistics 2017. Jakarta: BPSStatistic Indonesia, 2018.

[15] J. Wacik, Peraturan Menteri ESDM No. 25 Tahun 2013 tentang Perubahan atas Peraturan Menteri Energi dan Sumber Daya Mineral Nomor 32 Tahun 2008 tentang Penyediaan, Pemanfaatan, dan Tata Niaga Bahan Bakar Nabati (Biofuel) Sebagai Bahan Bakar Lain. Jakarta: Kementerian Energi dan Sumber Daya Mineral, 2013.

[16] International Energy Agency, Power Generation from Coal: On-Going Developments and Outlook. Paris: International Energy Agency, 2011.

[17] U.S. Environtmental Protection Agency, Fuel Economy Guide Model Year 2020. Washington, D. C.: U.S. Department of Energy, 2020.

[18] Intergovernmental Panel of Climate Change, "IPCC emission factor database," in UN Climate Change Conference, Katowice, Poland, 2018.

[19] J. P. Stempien and S. H. Chan, "Comparative study of fuel cell, battery and hybrid buses for renewable energy constrained areas," J. Power Sources, vol. 340, pp. 347-355, 2017.

[20] N. O. Nylund and K. Erkkilä, "Heavy-duty truck emission and fuel consumption simulating realworld driving in laboratory condition," in 2005 DEER Conf., Chicago, Illinois, USA, Aug. 2005, p. 23. 